\title{
DÜBLIN
}

Technological University Dublin ARROW@TU Dublin

2013-04-30

\section{Digital Reading: A Question of Prelectio?}

\author{
Noel Fitzpatrick \\ Technological University Dublin, noel.fitzpatrick@tudublin.ie
}

Follow this and additional works at: https://arrow.tudublin.ie/aaschap

Part of the Continental Philosophy Commons, and the Reading and Language Commons

\section{Recommended Citation}

Fitzpatrick, N. (2013). Digital Reading: A Question of Prelectio?. In C. Fowley, C. English, \& S. Thouësny (Eds.), Internet Research, Theory, and Practice: Perspectives from Ireland (pp. 1-16). Dublin: @ Researchpublishing.net.

This Book Chapter is brought to you for free and open access by the Fine Arts at ARROW@TU Dublin. It has been accepted for inclusion in Books/Book Chapters by an authorized administrator of ARROW@TU Dublin. For more information, please contact arrow.admin@tudublin.ie, aisling.coyne@tudublin.ie, gerard.connolly@tudublin.ie.

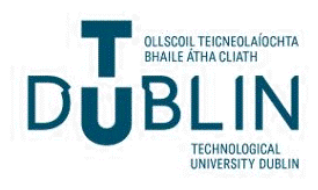




\title{
Digital Reading: \\ A Question of Prelectio?
}

\author{
Noel Fitzpatrick ${ }^{1}$
}

\section{Abstract}

$\mathrm{D}$ igital reading as superficial reading is examined by demonstrating that technologies act as placeholders for different types of memory, artificial memory and true memory. This chapter argues that the affordances of digital technologies enable certain types of reading activity, digital reading, but hinders others, such as deep reading. In particular, there is a tenuous relationship between digital reading and scanning for information in the printed text, a form of reading traditionally known as prelectio. This latter is a pre-reading of the text for salient information, not for deep understanding: it is, rather, a scanning or skimming of the text. Since the development of digital reading, there has been a debate about the role taken by digital technologies in the acquisition of reading as an activity. This chapter will, through the analysis of the recent works of Stiegler (2010) and the research group Ars Industrialis, challenge the outright rejection of the digital technologies of reading. Instead, by revisiting the technology of writing as a cure and a poison, as a pharmakon, a positive pharmacology will be proposed. By re-examining the philosophical problematic of reading and writing, the first step of this positive pharmacology will be to identify the necessary curative aspects of the technology.

Keywords: digital reading, prelectio, narratio, lectio, Generation M, cognitive overflow, pharmakon, Stiegler.

1. The School of Art, Design and Printing, Dublin Institute of Technology, Dublin, Ireland; noel.fitzpatrick@dit.ie

How to cite this chapter: Fitzpatrick, N. (2013). Digital Reading: A Question of Prelectio?. In C. Fowley, C. English, \& S. Thouësny (Eds.), Internet Research, Theory, and Practice: Perspectives from Ireland (pp. 1-16). Dublin: (C) Research-publishing.net. 


\section{Introduction}

This chapter sets out to counter a train of thought which posits the technologies of digital reading as the root of a decline in reading and as the cause for the development of surface reading. It questions the claim that the technologies themselves lead to a type of reading which remains on the surface and hinders readers from developing more reflective reading practices. In order to counter this argument, the chapter highlights the principal reasons for rejecting digital reading as a form of pre-reading exercise, a prelectio. Then this chapter examines the relationship between different types of reading and contextualises the philosophical problematic of reading by investigating current writing within the work of French philosopher Stiegler (2010). The chapter attempts to determine the first steps in the revisiting of digital technologies of reading as a positive remedy to enable the development of deeper reading.

There is a wealth of research dealing with digital literacy. In America the debate has focused on the decrease in reading habits and the growth of digital forms of reading (Cartelli, 2012). In the US, it is claimed that Generation M are reading less and less printed texts. The term Generation $M$ was used to describe the generation of 8-18 year olds as a media generation and it came from the title of a report written in 2005, which investigates the use of media by this age group (Roberts, Foehr, \& Rideout, 2005). Generation $M$ are reading less and less, we are told, but at the same time they are reading more and more online, using media other than the printed text. However, digital reading is a specific form of reading, a specific form of tekhne, and therefore requires specific analysis.

In order to come to a fuller understanding of the impact of digital technologies on reading, we need to revisit the form of reading which takes place on screen. This chapter will argue that there is a specific form of reading, a prelectio, which is enabled by the form of the text on screen. Whether this form of reading is detrimental to more sustained deep reading is a moot point within literacy studies. The outright rejection of digital technology has become more prevalent through a series of recent publications where the analysis of the detrimental 
effect of digital reading is embedded within a discourse which highlights the negative effects of technology. Bauerlein (2008), in his book The Dumbest Generation: How the Digital Age Stupefies Young Americans and Jeopardizes Our Future, rejects internet technologies, as is evident from the provocative title. Bauerlein (2008) argues that a decline in reading is directly linked to two main factors: the decrease in print reading and the growth of digital texts. He also argues that there is no transfer from digital reading to print reading, going so far as stating that digital reading does not develop strong reading skills (Bauerlein, 2008, pp. 93-111).

Another example is Carr (2011) in his book The Shallows: What the internet is doing to our Brains; Carr (2011) takes a slightly different slant but one which, nonetheless, rejects digital reading, identifying it as a form of surface reading. His analysis of his personal experience of reading in the digital age details the development of his addiction to skimming along the surface, a pathological internet usage. He describes this addiction as a form of inattention, skipping from screen to screen, and not allowing the time or space for reflection and deeper reading. Both authors illustrate a tendency at the moment to view the technological tools of digital reading as a 'scapegoat': a pharmakos.

\section{Surface reading and deep reading}

However, the specific form of reading which Carr (2011) and Bauerlein (2008) refer to as surface reading has its parallel in another form of surface reading which has a long history in relation to reading and education: the prelectio. In the study of rhetoric, prelectio can be dated back to the first century, to Quinitilian, and then extends through monastic traditions to John of Salisbury (1180) and Bernard de Chartes (c.1130). In order to comprehend what is at stake in drawing a parallel between surface reading in digital technologies and prelectio, it is necessary to give a brief historical account of the latter. In the monastic tradition techniques were developed to decipher texts without reading in detail. Thus, it is argued that word separation and prelectio were part of the development of silent reading (Saenger, 1991). The monks were 
amongst the first to establish canonical word separation. At that time, romance latin of the early biblical texts had fallen into disuse, and texts were blocks, scriptura continua, without punctuation or word separation. The texts were read out loud; hence, the lack of punctuation. Saenger (1997) in his book Space Between Words: The Origins of Silent Reading demonstrates that the practice of canonical word separation led to the growth of silent individual reading in the monasteries. Word separation, therefore, became the norm. The reading of the text to first establish word separation was a scanning for information in the text, not for its meaning: the monks skimmed the surface of the text in order to separate out the words before engaging in a deeper reading. This initial scanning for information or pre-reading of the text was an essential part of the process of deciphering the morphological structure of text; the ability to move from prelectio to narratio or lectio was central to the reading process in the monastic tradition: one enables the other and is not exclusive of the other. The movement is from a pre-reading for information to a detailed reading for meaning, from scanning to semantics, from prelectio to lectio.

Reading as lectio was a silent reflective activity, associated with learning and meditation. Saint Augustine, mentioned in Outler (1955), points to the relationship between reading and meditation. The reader's eye glances from the page to an inner eye of reflection and meditation:

"Thus he spoke, and in the pangs of the travail of the new life he turned his eyes again onto the page and continued reading; he was inwardly changed, as thou didst see, and the world dropped away from his mind, as soon became plain to others. For as he read with a heart like a stormy sea, more than once he groaned. Finally he saw the better course, and resolved on it" (cited in Outler, 1955, book 8, chapter 6, para. 15).

Prelectio, lectio and narratio were seen as part of the approach to the pedagogy of reading (Minnis, 1994). The parallel is, therefore, a movement from scanning to comprehension which constitutes an inherent relationship between both forms of reading: surface reading enables deeper reading, they are not mutually exclusive reading activities. The type of reading involved in the implementation 
of word separation in the monastic tradition is akin to techniques used in natural language processing, which are widely used; texts are parsed and analysed in terms of the smallest unit or n-gram. The text is analysed in terms of its surface characteristics: spaces, full stops and punctuation markers, which, it can be argued, is a form of surface reading of texts. However, in natural language processing the movement from the statistical surface information to the deeper semantics has been much more difficult than initially thought. The semantics of the semantic web today remain a goal of artificial intelligent systems but remain unattainable.

\section{Digital reading and inattention}

Hayles (2007) sets out to understand why students in third level education are reading less and less in the humanities. She demonstrates that there is a cognitive divide between generations. Generation $M$ are finding it more difficult to read novels because of their inability to attend to the texts for sustained periods of reading. Hayles (2007) argues that there is an opposition between the types of attention involved in different media, print and digital, and that reading as an activity requires deep attention while the use of digital technologies necessitates hyper-attention. The skipping from screen to screen reflects a more profound problematic of inattention:

"Deep attention, the cognitive style traditionally associated with the humanities, is characterized by concentrating on a single object for long periods (say, a novel by Dickens), ignoring outside stimuli while so engaged, preferring a single information stream, and having a high tolerance for long focus times. Hyper-attention is characterized by switching focus rapidly among different tasks, preferring multiple information streams, seeking a high level of stimulation, and having a low tolerance for boredom" (Hayles, 2007, p. 187).

The hyper-attention involved in switching rapidly from task to task is, therefore, a form of inattention, leading to the inability to concentrate for 
sustained periods of time. Hayles (2007) points to the development of a generation in America where deficit hyperactivity disorder (ADHD) is on the increase. Ritalin, the drug used to treat children with ADHD stimulates the brain so that the activity is increased, the drug acting as cortical stimulant. Hyperactivity is therefore sustained, to avoid boredom setting in. If Carr (2011) and Bauerlein (2008)highlight hyper-attention or inattention as part of digital reading, Hayles (2007) links it to a wider issue in relation to digital technologies and the development of other forms of inattention. However, Hayles (2007) does not dismiss technologies as the 'scapegoat' but attempts to offer examples of how hyper-attention and attention could be developed as specific pedagogical strategies, where e-learning or blended learning could harness the technologies of hyperactivity for positive use. The emergence of serious games, for example, highlights the positive learning opportunities afforded by the use of gaming technologies in education. Positive aspects thus include the ability to handle multiple tasks and to strategise. Hyper-attention and attention should not therefore be seen as mutually exclusive; ADHD may be an extreme point on the continuum of inattention, yet hyper-attention linked to digital technologies could be used to engage new generations into more sustained attention. She concludes by stating:

"Whether inclined toward deep or hyper-attention, toward one side or another of the generational divide separating print from digital culture, we cannot afford to ignore the frustrating, zesty, and intriguing ways in which the two cognitive modes interact. Our responsibilities as educators, not to mention our position as practitioners of the literary arts, require nothing less" (Hayles, 2007, p. 198).

The design of reading activities in higher education must include educational opportunities which enable the two cognitive forms to interact. However, the problematic of reading in the twenty first century is not just about cognition. Reading has also become part of a powerful and commercially successful 'reading industry', a term coined by Giffard (2009) to describe an industry which seeks the traces we leave on the web as part of our daily reading activity and offers them as a good to be bought, sold and monetised. 


\title{
4. Digital reading as a form of surface reading
}

The relationship between prelectio and digital reading is that both are based on reading for information and not reading for content. The type of reading offered by early pre-web screen reading is akin to the monastic prelectio for word separation. As Giffard (2009) points out:

\begin{abstract}
"Before the web, in the practice of reading on a screen, the text is not the objective of the reader. Rather is it a control reading, a certain way to decipher and survey the informations (sic) and operations of the computer. And reading is submitted to another activity that is the real goal. Credit card, word processor, phototypesetting are examples of such a "reading on a screen". Umberto Eco has said "word processor e una machina molto spirituale" but reading functionalities of word processor are not spirituals at all" (Section "Digital reading is reading", para. 4).
\end{abstract}

Reading on screen is akin to the prelectio, reading for information, a control reading to ensure that the information being portrayed is correct or incorrect. This functional reading is not a spiritual one of meditation i.e., lectio. Giffard (2009) argues that this form of reading for information is inherent in any screen reading and is now so widespread as to be second nature to our relationship with digital technologies. The affordances of the technologies in place lead to the predominance of a prelectio.

Embedded in 'digital reading' is a form of hyper-attention because the reader is distracted from the principal task at hand. The model of comprehension of the text is interrupted by the technology itself; there is a distraction built into the very interface of the digital technology being used. The reader is cognitively aware of choices being made or not made at the same time that reading takes place. This leads to what is referred to as cognitive overflow. Reading in itself is a highly challenging cognitive activity - a young child learning to read is the proof of how challenging it can be - and in addition to this complex cognitive activity, digital reading intersperses supplementary cognitive demands such as hyperlinks. Hyperlinks, which may or may not be clicked on, act as a distraction 
from the principal task at hand. In addition, there is the distraction inherent to the very interface, the technology, the screen renewing, the backlight, the layout of the page on screen and often the use of poor typography. The challenges of reading online lead to distraction:

"As opposed to the relative linearity of printed text, the very appearance of digital information at once presents both new richness and new challenges for the online reader. The fluid, multimodal nature of digital information enables online readers to become immersed in a subject, both visually and verbally. Even as this presentation of material in several different modes provides the reader with multiple points of entry into a subject, it also opens the door to great distraction. It further requires that the reader understand how to evaluate visual information and make meaning in and across several different modalities" (Wolf \& Barzillai, 2009, p. 135).

All of these lead to a distraction within the distraction, a type of hyper-attention which leads to a surface reading of the text, and this constant distraction is an object of criticism, as discussed above. The distraction impinges on the reader's ability to move from surface to deep reading, a reading that enables reflection and understanding, and which for Saint Augustine allowed the development of the spirit (Outler, 1955). But Giffard (2011) also posits a positive alternative to this deterministic vision of technology:

“Evoquons enfin une autre orientation de Carr et ce qu'il faut bien appeler sa vision déterministe de la technique. L'auteur semble prisonnier de l'hypothèse de McLuhan selon laquelle le medium définit le message. D'autre part, il n'envisage pas la possibilité que le lecteur, par un régime d'exercices appropriés, puisse conquérir son autonomie par rapport au dispositif technique, voire le détourner. Le formatage de la lecture par l'internet est la logique qui s'impose à l'exclusion de toute autre" (Giffard, 2011, section "Une vision déterministe de la technique", para. 1).

Lastly to mention Carr's other orientation and which must be called his determinist vision of technology. The author seems to be a prisoner of 
McLuhan's hypothesis according to which the medium is the message. In addition, he does not envisage the possibility that through a mechanism of appropriate exercises the reader could attain their autonomy in relation to the technological dispositive, or even overcome it. The formatting of reading by the internet is a logic which imposes itself to the exclusion of any other.

In opposition to the outright rejection of digital reading as a form of surface reading Giffard (2011) is proposing to go beyond Carr's (2011) deterministic view of digital technologies and offers positive alternatives.

\section{Reading and writing: the positive pharmakon}

To further explore how this positive alternative may develop, it is necessary to place the debate within a philosophical context of the notion of the text: reading and writing as a form of problematic. Whilst this is a well-rehearsed argument within contemporary philosophy it is necessary here to revisit a recent development in the understanding of writing as a pharmakon (Ricoeur, 2004). Stiegler (2010) has developed what he terms a positive pharmacology or therapeutic. In the quotation from Giffard (2011) above we can glimpse how this positive pharmacology could come to fruition in relation to digital reading. The criticism which is made of Carr's (2011) position could be summarised in terms of an over emphasis upon the negative aspect of digital reading which leads the positing of surface reading, the prelectio, as the ultimate end point of all digital reading.

In the background to Stiegler's (2010) analysis of a positive pharmacology is the analysis of writing as a pharmakon. Stiegler (2010) retraces the philosophical debate in relation to reading and writing as problematic back through Derrida (1981) to Plato. There is an irony here, as Plato was opposed to writing as a pharmakon, something which was not good for the brain and not good for memory. Analyses of digital reading show a similar reticence: digital reading, it is argued, leads to a form of reading which is also bad for 
the brain because it leads to a form of hyper-attention. Derrida (1981) in his work Dissemination wrote a long essay entitled Plato's Pharmacy. This text has become a central part of the canon of philosophical texts in relation to the development of Derrida's (1981) shift from grammatology to deconstruction. In this essay Derrida (1981) gives a sustained micro-reading of Plato's (370 BC/1985) Phaedrus, with a critique of Plato's position on writing as a pharmakon, that is, a cure and a poison. Pharmakon is the etymological root of pharmacology, the study of cure as poison and poison as cure. Writing, for Plato, is a poison in the sense that writing divorces speech from meaning. The absence of the interlocutor leads to a position whereby the text could say what the writer did not intend it to say. Writing enables the misconstruction of meaning; the absence of the speaker leads to untruth. Derrida (1981) describes this as the phonocentric position that Plato holds. Writing is also a poison in relation to memory/reminding:

"The fact is that this invention [writing] will produce forgetfulness in the souls of those who have learned it because they will not need to exercise their memories [...], being able to rely on what is written, using the stimulus of external marks that are alien to themselves [...] rather than, from within, their own unaided powers to call things to mind [...]. So it's not a remedy for memory, but for reminding, that you discovered (oukoun mnẽmẽs, alla hupomnẽseõs, pharmakon hẽures). And as for wisdom [...], you're equipping your pupils with only a semblance [...] of it, not with truth" (Plato, 370 BC/1985, 274e-275b, cited in Derrida, 1981, pp. 104105 , emphasis in original).

The pharmakon is here played out in its ambiguity, it is not a cure for memory (mnemes) but for reminding (hypomnesis), this latter refers to the act of technical regurgitation, an artificial memory, a mechanism of reminding. It is therefore to repeat without thought. The distinction which Plato/Socrates makes is between memory and artificial memory. True memory takes the form of the dialectic, dialogos through which truth can disclose itself as alethea. For Plato writing does not enable anamnesis, true memory, but enables a mechanical repetition which does not lead to the truth. Writing is a form of hypomnesis, an artificial 
holding place of memory, a mechanism for repetition and not thought. This is where the ambiguity of the word pharmakon comes to the fore. Derrida's (1981) critique of Plato and by extension of all Western metaphysics is grounded in his criticism of Plato's rejection of writing. However, more recently with the work of Stiegler (2010) this criticism was revisited, and the opposition between anamnesis and hypomnesis as outlined by Derrida (1981) now leads to a positive pharmacology, the remedy. Derrida (1981) never envisaged the curative aspect of pharmacology, the positive pharmacology which Stiegler (2010) posits. Stiegler (2010) develops an understanding of the pharmakon as cure and poison, building upon Derrida's (1981) identification of the semantics of remedy that are present in Plato's text:

"we hope to display in the most striking manner the regular, ordered polysemy that has, through skewing, indetermination, or overdetermination, but without mistranslation, permitted the rendering of the same word by "remedy", "recipe", "poison", “drug”, "philter", etc. It will also be seen to what extent the malleable unity of this concept, or rather its rules and the strange logic that links it with its signifier, has been dispersed, masked, obliterated, and rendered almost unreadable not only by the imprudence or empiricism of the translators, but first and foremost by the redoubtable, irreducible difficulty of translation" (Derrida, 1981, p. 77).

The pharmakon as cure and poison demonstrates the difficulty of language to hold a primacy of meaning, a unity of signification. Indeed the pharmakon demonstrates the dispersal of the signifier which is the very basis of Derrida's (1981) deconstruction. Derrida's (1981) primary challenge is that Plato's critique of writing as used by the Sophists relates to the idea that it is essentially a poison for reminding and not for memory.

For Stiegler (2010), writing is the very condition of thinking itself, a process of meta-categorisation which is essential to a reflective, recursive process:

“Le pharmakon, qu'est l'écriture - comme hypomnésis, hypomnématon, c'est-à-dire mémoire artificielle - est ce dont Platon combat les effets 
empoisonnants et artificieux en y opposant l'anamnésis : la pensée "par soi-même", c'est-à-dire l'autonomie de la pensée" (p. 13, emphasis in original).

The pharmakon, which is writing - as hypomnesis, hypomnematon, that is to say artificial memory - is that of which Plato fights the noxious and artificial effects by opposing it to anamnesis: thinking for oneself, i.e., the autonomy of thought.

Writing is poisonous because it is a form of artificial memory which leads to forgetfulness, memory is exteriorised in the tekhne itself as a form of mnemotechnics. The affordances of technology for digital reading lead to a form of forgetfulness, all technology leads to a form of forgetfulness. Digital technologies function as placeholders for memory, in the same way as, for Plato, writing functions as placeholder for speech. For Stiegler (2010), there is an inherent link between the development of technologies and a proletarianisation of knowledge which leads ultimately to a loss of knowledge:

"A cet égard, le pharmakon constitue un facteur de prolétarisation de l'esprit (de perte de savoir) tout comme la machine-outil prolétarisera les corps des ouvriers producteurs (les privera de leur savoir-faire)" (p. 40, emphasis in original).

In this way, the Pharmakon constitutes a factor of proletarnisation of the spirit (loss of knowledge) just as the machine-tool proletarised the bodies of the manual workers (Which took away their know how).

The consequence of the pharmakon is the loss of knowledge. The concept of forgetfulness which Plato highlights in relation to writing is developed and expanded by Stiegler (2010) in relation to all forms of technology. For Stiegler (2010) the loss of knowledge leads to the pharmacological situation representative of the contemporary situation in the West: financial, political and social crisis. However, it is necessary to point out that this should not be misconstrued as a rejection of the technology of writing or technology itself. 
Stiegler (2010) is mindful of the current of thought which uses technology as the scapegoat, as a pharmakos, for all the failures and shortcomings of society, a current of thought which rejects the technologies (of the spirit). This trend does not take into account that the very spirit itself is at the origin and constitutive of the pharmakon or the pharma-logico:

“Rien n'est plus légitime que ces luttes philosophiques contre ce qui, dans la technique ou la technologie, est toxique pour la vie de l'esprit. Mais face à ce qui, dans le pharmakon, constitue la possibilité d'un affaiblissement de l'esprit, ces luttes choisissent aussi d'ignorer la constitution originairement pharma-logique de l'esprit lui-même. Elles choisissent d'ignorer la pharmacologie de l'esprit en faisant du pharmakon en général un pharmakos : un bouc émissaire - celui des pratiques sacrificielles en Grèce ancienne polythéiste, que l'on trouve également en Judée, ou ce pharmakos est chargé, comme le sera le Christ, de toutes fautes qu'il emmène vers une région inaccessible" (Stiegler, 2010, p. 40, emphasis in original).

Nothing is more legitimate than the philosophical disputes against that which, in the technic or the technology, are toxic for the spirit. But against which, in the pharmakon, constitutes the possibility of the weakening of the spirit/mind, the disputes choose to ignore the original pharma-logic constitution of this spirit itself. They choose to ignore the pharmacology of the spirit by making the pharmakon in general a pharmakos: a scapegoat, the scapegoat of the polytheist ancient Greece, which is also found in Judea, where the pharmakos is charged, as will Christ, with all the faults that he brings him to an inaccessible region.

Stiegler (2010) contends that technology is part and parcel of who we are and writing is a form of technology which enables reflection to develop, that there are elements of technology which are poisonous to the mind, but there is a pharmacology of the spirit. It is possible to envisage a positive pharmacology of the spirit which entails the development of technology as primary, secondary and tertiary retention. The process of individuating ourselves, becoming who 
we are through differentiation takes place through the constant development of technology. This is a process of becoming, an ontology of becoming which is inherently present in the technologies that we develop. In this short essay we do not have the time to develop these key concepts further. However, the relationship between different forms of memory which leads to Plato's dismissal of writing as remedy for reminding is overcome by Stiegler's (2010) analysis of the relationship between different types of retention, primary, secondary and tertiary. Stiegler's (2010) analysis points to the short circuit which is afforded by writing as hypomnesis. Hypomnesis is constitutive of anamnesis. In Plato's terms the remedy for reminding is constitutive of true memory itself.

\section{Conclusion}

The recognition that the relationship between the nefarious and curative aspects of the pharmakon is necessary as the first step towards identifying the curative aspects of the pharmakon. The simple accusation that the pharmakon as technology is the root of all evil is one which Stiegler (2010) rejects outright. We cannot be for or against technology: technology is an inherent part of who we are and who we are becoming. The question itself therefore borders on the nonsensical, akin to being for or against the sun. The opposition between pharmakon as cure and as poison has led to a misunderstanding in relation to the development of writing. For Stiegler (2010), anamnesis is inherently linked to hypomnesis and hypomnesis to anamnesis. The critique, therefore, of digital reading as a reading which leads to cognitive overflow and hyper-attention and hence to surface reading, as Carr (2011) proposes, misses the extent to which the technic of artificial memory is embedded in the very technologies themselves which form part of who we are. The simple dichotomy of print reading as deep attention and digital reading as hyper-attention leading to surface reading is one which needs to countered. The opposition between writing as a form of artificial memory and speech as a form of true memory has led the philosophical debate to revisit the pharmakon as possibility for positive development. This is the first step towards a positive pharmacology, a new 
therapeutics, a pharmacology which attempts to go beyond the noxious effects of the poison and moves towards the remedy. In relation to hyper-attention and deep attention there is the possibility of re-harnessing the technologies of reading to enable deep reflection to take place. Hence, for example, whilst the industry of reading offers technologies which monetise reading activities, developments in computational linguistics are offering new approaches to textual analysis and reading, where the tools of discourse analysis enable large corpuses to be indexed and available for new types of literary analysis. Carr (2011) and Bauerlin (2008) offer a pessimistic vision of digital reading for the future and, more importantly, demonstrate an understanding of the brain which does not take into account the plasticity of its development. Wolf (2007), however, offers a more optimistic approach to the development of the brain and reading:

"Thus the reading brain is part of highly successful two-way dynamics. Reading can be learned only because of the brain's plastic design, and when reading takes place, that individual brain is forever changed, both physiologically and intellectually" (p. 5).

The future of digital reading, if we accept the analyses of Giffard (2011) and Stiegler (2010), is reliant on the ability to revisit the very technologies of reading as a mechanism of re-harnessing thought, rearming thought. By revisiting the inherent design and typographic problems present in digital text we are offered an opportunity to rearm thought through the technologies of thought itself. The positive pharmacology is one which accepts the pharmakon as a poison but embraces the pharmakon as a possible means of therapeutic development.

\section{References}

Bauerlein, M. (2008). The Dumbest Generation: How the Digital Age Stupefies Young Americans and Jeopardizes our Future. New York: Penguin books.

Carr, N. (2011). The Shallows: what the internet is doing to our brains. New York: Norton and Company. 
Cartelli, A. (2012). Current Trends and Future Practices for Digital Literacy and Competence. Hershey, PA: IGI Global.

Derrida, J. (1981). Dissemination. Chicago: University Press of Chicago.

Giffard, A. (2009). Digital Reading, industrial reading [weblog]. Retrieved from http:// alaingiffard.wordpress.com/2009/07/11/digital-reading-industrial-readings/

Giffard, A. (2011). A propos du livre de Nicholas Carr [weblog]. Retrieved from http:// alaingiffard.blogs.com/culture/2011/11/a-propos-du-livre-de-nicholas-carr.html

Hayles, N. K. (2007). Hyper and Deep Attention: The Generational Divide in Cognitive Modes. Profession, 13, 187-199. doi: 10.1632/prof.2007.2007.1.187

Minnis, A. J. (1994). The Medieval Concept of the Author. In D. Graddol \& O. Boyd-Barrett (Eds.), Media Texts: Authors and Readers (pp. 161-165). Oxford: The Oxford University Press.

Outler, A. C. (Ed.). (1955). Augustine: Confessions (Newly Translated and Edited). Retrieved from http://www9.georgetown.edu/faculty/jod/augustine/conf.pdf

Plato. (370 BC/1985). Phaedrus (Phèdre. Greek text with French translation by Léon Robin). Paris: Edition Belles Lettres Budé.

Ricoeur, P. (2004).

Roberts, D. F., Foehr, U. G., \& Rideout, V. (2005). Generation M: Media in the Lives of 8-18-Year-Olds. A Kaiser Family Foundation Study. Retrieved from http://www.kff.org/ entmedia/upload/Generation-M-Media-in-the-Lives-of-8-18-Year-olds-Report.pdf

Saenger, P. (1991). The separation of words and the physiology of reading. In D. R. Olson \& N. Torrance (Eds.), Literacy and Orality (pp. 198-214). Cambridge: Cambridge University Press.

Saenger, P. (1997). Space Between Words: The origins of silent reading. Standford: Standford University Press.

Stiegler, B. (2010). Ce qui fait que la vie vaut la peine d'être vécue: De la pharmacologie. Paris: Flammarion.

Wolf, M. (2007). Proust and the Squid: The Story and Science of the Reading Brain. New York: HarperCollins Publishers.

Wolf, M., \& Barzillai, M. (2009). The importance of deep reading. Educational Leadership, 66(6), 32-37. Retrieved from http://www.ascd.org/ascd/pdf/journals/ed_lead/el200903_ wolf.pdf 